\title{
Perturbation of cytochrome P450, generation of oxidative stress and induction of DNA damage in Cyprinus carpio exposed in situ to potable surface water
}

\author{
Andrea Sapone ${ }^{\mathrm{a}}$, Bianca Gustavino ${ }^{\mathrm{c}}$, Monica Monfrinotti ${ }^{\mathrm{c}}$, Donatella Canistro ${ }^{\mathrm{a}}$, \\ Massimiliano Broccoli ${ }^{a}$, Laura Pozzetti ${ }^{a}$, Alessandra Affatato ${ }^{a}$, Luca Valgimigli ${ }^{b}$, \\ Giorgio Cantelli Forti ${ }^{a}$, Gian Franco Pedulli ${ }^{\mathrm{b}}$, Gian Luigi Biagi ${ }^{\mathrm{a}}$, \\ Sherif Z. Abdel-Rahman ${ }^{\mathrm{d}, *}$, Moreno Paolini ${ }^{\mathrm{a}}$ \\ a Dipartimento di Farmacologia, Alma-Mater Studiorum, Università di Bologna, Bologna \\ b Dipartimento di Chimica Organica “A. Mangini”, Alma-Mater Studiorum, Università di Bologna, Bologna \\ c Dipartimento di Biologia, Università di Roma "Tor Vergata", Roma, Italy \\ ${ }^{\mathrm{d}}$ Department of Preventive Medicine and Community Health, Division of Environmental Toxicology, \\ 700 Harborside Drive, The University of Texas Medical Branch, Galveston, TX 77555-1110, USA
}

Received 15 December 2005; received in revised form 27 September 2006; accepted 28 September 2006

Available online 1 December 2006

\begin{abstract}
Epidemiological evidence suggests a link between consumption of chlorinated drinking water and various cancers. Chlorination of water rich in organic chemicals produces carcinogenic organochlorine by-products (OBPs) such as trihalomethanes and haloacetic acids. Since the discovery of the first OBP in the 1970s, there have been several investigations designed to determine the biological effects of single chemicals or small artificial OBP combinations. However, there is still insufficient information regarding the general biological response to these compounds, and further studies are still needed to evaluate their potential genotoxic effects. In the current study, we evaluated the effect of three drinking water disinfectants on the activity of cytochrome P450 (CYP)-linked metabolizing enzymes and on the generation of oxidative stress in the livers of male and female Cyprinus carpio fish (carp). The fish were exposed in situ for up 20 days to surface water obtained from the Trasmene lake in Italy. The water was treated with 1-2 mg/L of either sodium hypochlorite $(\mathrm{NaClO})$ or chlorine dioxide $\left(\mathrm{ClO}_{2}\right)$ as traditional disinfectants or with a relatively new disinfectant product, peracetic acid (PAA). Micronucleus (MN) frequencies in circulating erythrocytes from the fish were also analysed as a biomarker of genotoxic effect. In the CYP-linked enzyme assays, a significant induction (up to a 57-fold increase in the deethylation of ethoxyresorufin with PAA treatment) and a notable inactivation (up to almost a $90 \%$ loss in hydroxylation of $p$-nitrophenol with all disinfectants, and of testosterone $2 \beta$-hydroxylation with $\mathrm{NaClO}$ ) was observed in subcellular liver preparations from exposed fish. Using the electron paramagnetic resonance (EPR) spectroscopy radical-probe technique, we also observed that CYP-modulation was associated with the production of reactive oxygen species (ROS). In addition, we found a significant increase in MN frequency in circulating erythrocytes after 10 days of exposure of fish to water treated with $\mathrm{ClO}_{2}$, while a non-significant six-fold increase in $\mathrm{MN}$ frequency was observed with $\mathrm{NaClO}$, but not with PAA. Our data suggest that the use of $\mathrm{ClO}_{2}$ and $\mathrm{NaClO}$ to disinfect drinking water could generate harmful OBP mixtures that are able to perturb CYP-mediated reactions, generate oxidative stress and induce
\end{abstract}

Abbreviations: $\mathrm{NaClO}$, sodium hypochlorite; $\mathrm{ClO}_{2}$, chlorine dioxide; PAA, peracetic acid; CYP, cytochrome P450; $\mathrm{MN}$, micronuclei; OBPs, organochlorine by-products; ROS, reactive oxygen species

* Corresponding author. Tel.: +1 409772 9111; fax: +1 4097729108.

E-mail address: sabdelra@utmb.edu (S.Z. Abdel-Rahman). 
genetic damage. These data may provide a mechanistic explanation for epidemiological studies linking consumption of chlorinated drinking water to increased risk of urinary, gastrointestinal and bladder cancers.

(C) 2006 Elsevier B.V. All rights reserved.

Keywords: Drinking water by-products; Cyprinus carpio; Cytochrome p450; Micronucleus; Organochlorine by-products; Cancer; ROS

\section{Introduction}

Chlorination is the most common means used to disinfect drinking water worldwide. However, while providing protection against pathogenic microorganisms, surface water disinfection may generate highly toxic byproducts, such as haloalkanes, haloacetic acids, haloacetonitriles, haloketones and haloaldehydes [1]. These compounds are derived from reactions of chlorine with humic and fulvic acids that are normally found in surface water [2-4]. A number of organochlorine by-products (OBPs) have been shown to be non-genotoxic carcinogens in laboratory animals $[5,6]$. These compounds are also able to induce mutagenic effects in some biological systems such as bacteria [7], polychaete [8], teleost fish $[9,10]$, mouse cells [11] and human B-lymphoblastoid cells [12]. Long-term studies in rats treated with the disinfectant sodium hypochlorite $(\mathrm{NaClO})$ in drinking water showed an increase in leukaemia in female rats [13]. Several epidemiological studies have suggested a link between consumption of chlorinated drinking water and increased risk of urinary and gastrointestinal tract cancers $[14,15]$. Studies linking the use of chlorinated water with the development of bladder cancer provide further support for this association [3]. Associations have also been found between consumption of drinking water with high OBP content and adverse reproductive outcomes, such as intrauterine growth retardation, spontaneous abortion and birth defects [16].

In drinking water, OBPs are present as a mixture of chemicals, with a composition that depends on the water source. Both in vitro genotoxicity [17] and in vivo carcinogenicity testing $[18,19]$ of different artificial mixtures of OBPs showed complex dose-dependent interactions that suggested an overestimation of the overall carcinogenic effect of this group of chemicals. While the current default risk assessment of chemical mixtures assumes that the carcinogenic effect of these chemicals is additive [20], long-term human exposure to OBP mixtures warrants further investigations into both the possible epigenetic and the genetic mechanisms of toxicity of these compounds. Results from these types of studies would help improve risk assessment and would aid efforts aimed at discovering alternative water disinfectants, as replacement for chlorine-containing chemicals, to reduce the risk of adverse health effects. One of the currently proposed alternative disinfectants that has received particular attention over the past few years is peracetic acid $\left(\mathrm{CH}_{3} \mathrm{COO}_{2} \mathrm{H}\right.$; PAA). This chemical is a potent antimicrobial agent with many applications in hospitals, laboratories and factories [21-23]. Disinfection of drinking water from lakes and rivers with PAA results in the production of carboxylic acids, which are known to be essentially non-mutagenic, with a very low level of genotoxicity in bacterial test systems [24,25].

In this work we evaluated the effects of two OBPproducing disinfectants $\left(\mathrm{NaClO}\right.$ and $\left.\mathrm{ClO}_{2}\right)$ and PAA in samples of treated lake water on the modulation of cytochrome P450 (CYP)-dependent biotransformation in the livers of Cyprinus carpio fish, and on the generation of reactive oxygen species (ROS). These endpoints were studied as possible surrogates for epigenetic mechanisms of carcinogenesis [26-32]. In addition, the DNA damaging potential of the two chlorinecontaining disinfectants and PAA was investigated using the micronucleus (MN) assay in circulating erythrocytes of these C. carpio fish that were exposed in situ (for up to 20 days) to surface waters treated with the three different disinfection protocols. The micronuclei originate from chromosome fragments or whole chromosomes that fail to engage with the mitotic spindle and therefore lag behind when the cell divides. The MN assay in circulating erythrocytes of several species of fish, including $C$. carpio, has been widely used in both in situ and in vivo exposure to environmental waters (for a comprehensive citation list see Ref. [43]). The relevance of the MN test in such a non-proliferating cell system relies on the MN-PCE test, formerly introduced in the mouse, though in fish erythrocytes the direct derivation of $\mathrm{MN}$-cells from the last proliferating event is not easily ascertainable by staining techniques. The appearance of $\mathrm{MN}$ in circulating fish erythrocytes is the ultimate step in their development. $\mathrm{MN}$ are generated by segregational errors (due to clastogenic and/or aneugenic events) taking place in the dividing erythropoietic stem cells in the cephalic kidney. According to data from different authors, the estimated time for detection of MN in circulating blood erythrocytes ranges between the second and third week after a clastogenic treatment $[9,10]$, which is compatible 
with the requirement of at least 100 days for a complete turnover of circulating erythrocytes.

In this study, we used concentrations of $\mathrm{NaClO}$, chlorine dioxide $\left(\mathrm{ClO}_{2}\right)$ and PAA that are normally utilized for water disinfection. The experiments were conducted with samples of water from a drinking water pilot plant within the water treatment complex of Castiglione del Lago in Perugia, Italy, where water from Trasmene lake is usually disinfected.

\section{Materials and methods}

\subsection{Lake water}

Trasmene lake in Perugia, Italy, a mesotrophic limnic environment, was chosen as a test site because the surface water has a high concentration of bromide and total organic carbon, which are possible precursors of mutagenic disinfection by-products.

\subsection{Water treatment pilot plant}

The following functional units were the main components of the pilot plant:

(1) A lake water capturing system.

(2) A sedimentation system (Corby 10, FZ Fantoni, Bedizzole, Italy), with two $1 \mathrm{~m}^{3}$ reservoirs to clarify the water.

(3) A filtration system (a $50 \mu \mathrm{m}$ pore size inox stainless steel filter followed by a $25 \mu \mathrm{m}$ pore size filter cloth) to remove suspended particles (Fluxa Filtri S.p.A., Milan, Italy).

(4) A pumping system in which sulphuric acid is added to neutralize the water to $\mathrm{pH}$ 7.0.

(5) One main pipeline divided into secondary ones that supply filtered water (flux $300 \mathrm{~L} / \mathrm{h}$ ) to four $300 \mathrm{~L}$ stainless basins (contact basins).

(6) Four contact basins, one with untreated water and three in which water was in contact with and interacted with disinfectants used in the experiments.

(7) Four $1 \mathrm{~m}^{3}$ stainless steel basins (exposure basins) used for in situ exposure of the fish. These basins received the water flowing from the contact basins.

\subsection{Disinfectants}

Briefly, the disinfectants tested were added to the water received from the Trasmene lake as follows:

(1) Peracetic acid (PAA; $\mathrm{CH}_{3} \mathrm{COO}_{2} \mathrm{H}$ obtained from Promox S.r.l. Leggiuno, VA, Italy), supplied as a $15 \%$ solution through a membrane pump.

(2) Sodium hypochlorite (NaClO; Solvay S.p.A., Rosignano, LI, Italy), supplied as a $14.5-15.5 \%$ solution through a membrane pump.
(3) Chlorine dioxide $\left(\mathrm{ClO}_{2}\right)$, produced on site in the pilot plant from an $8 \% \mathrm{NaClO}_{2}$ solution and a $10 \% \mathrm{HCl}$ solution through an automated generator (Tecme S.r.l., Gardolo di Trento, TN, Italy).

The mean ( \pm S.D.) concentration of each disinfectant added during the exposure was: $1.00 \pm 0.19 \mathrm{mg} / \mathrm{L}$ of PAA, $1.64 \pm 0.21 \mathrm{mg} / \mathrm{L}$ of $\mathrm{ClO}_{2}$, and $1.24 \pm 0.19 \mathrm{mg} / \mathrm{L}$ of $\mathrm{NaClO}$.

\subsection{Chemicals}

Nicotinamide adenine dinucleotide phosphate in its oxidized and reduced forms (NADP ${ }^{+}$and NADPH), pentoxyresorufin, methoxyresorufin, 7-ethoxyresorufin, $p$-nitrophenol, aminopyrine, glutathione, 16- $\alpha$-hydroxytestosterone, corticosterone and androste-4-ene-3,17-dione were purchased from Sigma Chemical Co. (St. Louis, MO, USA). Glucose 6-phosphate, glucose 6-phosphate dehydrogenase and cytochrome $c$ were from Boehringer-Mannheim (Germany). HPLC grade methanol, tetrahydrofuran and dichloromethane were acquired from Labscan Ltd. Co. (Dublin, Ireland), $7 \alpha-, 6 \beta$ - and $16 \beta$-hydroxytestosterone were from Sterlaloid (Wilton, NH, USA), $6 \alpha-, 2 \alpha-$ and $2 \beta$-hydroxytestosterone were a generous gift from Dr. P. Gervasi (CNR, Pisa, Italy). All other chemicals were of the highest purity commercially available.

\subsection{Acclimatization}

C. carpio were introduced into each basin before the start of the exposure, to allow acclimatization.

\subsection{Treatment of fish and preparation of subcellular fractions}

Male and female C. carpio (a species of fish commonly known as carp) obtained from the Trasmene lake were supplied by the 'Centro Ittiogenico di Sant'Arcangelo' (Perugia, Italy) with a weight ranging from $340 \mathrm{~g}$ to $420 \mathrm{~g}$ and were divided into four groups. After a period of 10 days of acclimatization, each group was placed in a different exposure basin containing surface water from the lake treated with $1-2 \mathrm{mg} / \mathrm{L}$ of one of three different disinfectants: PAA (a disinfectant that has not previously been used for drinking water), $\mathrm{NaClO}$, or $\mathrm{ClO}_{2}$. The fourth group was placed in untreated lake water to serve as an unexposed control. Following an exposure period of up to 20 days, the liver was rapidly removed from each fish, homogenized and then centrifuged at $9000 \times g$. The postmitochondrial supernatant was then centrifuged for $60 \mathrm{~min}$ at $105,000 \times g$, after which the pellet was resuspended in $0.1 \mathrm{M}$ $\mathrm{K}_{2} \mathrm{P}_{2} \mathrm{O}_{7}, 1 \mathrm{mmol} / \mathrm{L}$ EDTA $(\mathrm{pH}$ 7.4) and centrifuged again for $60 \mathrm{~min}$ at $105,000 \times g$ to give the final microsomal fraction. Washed microsomes were then suspended with a hand-driven potter Elvehjem homogenizer in a $10 \mathrm{mmol} / \mathrm{L}$ Tris-HCl buffer (pH 7.4) containing $1 \mathrm{mmol} / \mathrm{L}$ EDTA and $20 \%$ (v/v) glycerol. The fractions were immediately frozen in liquid nitrogen, 
stored at $-80^{\circ} \mathrm{C}$ and used within a week for enzymatic analyses [33].

\subsection{Assays for CYP-metabolizing enzyme activity}

\subsection{1. $C Y P 3 A 1 / 2$}

Preferential activity of CYP3A1/2 was determined using aminopyrine $N$-demethylase (APND) as a probe by quantification of formaldehyde release, according to Mazel [34]. The total incubation volume was $3 \mathrm{~mL}$, composed of $0.5 \mathrm{~mL}$ of a buffer solution of $50 \mathrm{mM}$ aminopyrine and $25 \mathrm{mM} \mathrm{MgCl} 2$, $1.48 \mathrm{~mL}$ of $0.60 \mathrm{mM} \mathrm{NADP}^{+}, 3.33 \mathrm{mM}$ glucose 6-phosphate in 50 mM Tris-HCl buffer (pH 7.4), $0.02 \mathrm{~mL}$ glucose 6-phosphate dehydrogenase $(0.93 \mathrm{U} / \mathrm{mL})$, and $0.125 \mathrm{~mL}$ of sample $(0.5 \mathrm{mg}$ of protein); under these conditions, the method was linear up to $\sim 50 \mathrm{nmol} \mathrm{mg}^{-1} \mathrm{~min}^{-1}$. After $5 \mathrm{~min}$ of incubation at $37^{\circ} \mathrm{C}$, the yellow color, caused by the reaction with the formaldehyde released with the Nash reagent, was read at $412 \mathrm{~nm}$ and the molar absorption of 8000 was used for calculation [35].

\subsection{2. $C Y P 2 E 1$}

CYP2E1-linked activity was determined using $p$ nitrophenol hydroxylase (PNH) as a probe. The incubation medium consisted of $2 \mathrm{mM} p$-nitrophenol in $50 \mathrm{mM}$ Tris- $\mathrm{HCl}$ buffer ( $\mathrm{pH}$ 7.4), $5 \mathrm{mM} \mathrm{MgCl}_{2}$ and a NADPH-generating system consisting of $0.4 \mathrm{mM} \mathrm{NADP}{ }^{+}, 30 \mathrm{mM}$ isocitrate, $0.2 \mathrm{U}$ of isocitrate dehydrogenase and $1.5 \mathrm{mg}$ of proteins in a final volume of $2 \mathrm{~mL}$, as previously described [36]. In brief, after $10 \mathrm{~min}$ at $37^{\circ} \mathrm{C}$, the reaction was stopped by adding $0.5 \mathrm{~mL}$ of $0.6 \mathrm{~N}$ perchloric acid. Under these conditions, the reaction was linear up to $\sim 5.5 \mathrm{nmol} \mathrm{mg}^{-1} \mathrm{~min}^{-1}$. Precipitated proteins were removed by centrifugation, and $1 \mathrm{~mL}$ of the supernatant was mixed with $1 \mathrm{~mL} 10 \mathrm{~N} \mathrm{NaOH}$. Absorbance at $546 \mathrm{~nm}$ was immediately measured and the concentration of 4-nitrocatechol determined $\left(\varepsilon=10.28 \mathrm{mM}^{-1} \mathrm{~cm}^{-1}\right)$.

\subsection{CYP2B1/2, CYP1A1 and CYP1A2}

Pentoxyresorufin $O$-dealkylase (PROD), ethoxyresorufin $O$-deethylase (EROD) and methoxyresorufin $O$-demethylase (MROD) were used as markers of CYP2B1/2, CYP1A1 and CYP1A2 activities, respectively. For measurement of PROD activity, the reaction mixture consisted of $0.025 \mathrm{mM} \mathrm{MgCl}_{2}$, $200 \mu \mathrm{M}$ pentoxyresorufin, $0.32 \mathrm{mg}$ of proteins and $130 \mathrm{mM}$ NADPH in $2.0 \mathrm{~mL} 0.05 \mathrm{M}$ Tris-HCl buffer (pH 7.4). Resorufin formation at $37^{\circ} \mathrm{C}$ was calculated by comparing the rate of increase in relative fluorescence to the fluorescence of known amounts of resorufin (excitation $562 \mathrm{~nm}$, emission $586 \mathrm{~nm}$ ) [37]. EROD and MROD activities were measured in the same way, except that the substrates were $1.7 \mu \mathrm{M}$ ethoxyresorufin and $5 \mu \mathrm{M}$ methoxyresorufin, respectively [38].

\subsection{Testosterone hydroxylase (TH)}

An incubation mixture was prepared containing liver microsomes (equivalent to $1-2 \mathrm{mg}$ protein), $0.6 \mathrm{mM} \mathrm{NADP}^{+}, 8 \mathrm{mM}$ glucose 6-phosphate, $1.4 \mathrm{U}$ glucose 6-phosphate dehydrogenase and $1 \mathrm{mM} \mathrm{MgCl}$, in a final volume of $2 \mathrm{~mL} 0.1 \mathrm{M}$ phosphate $\mathrm{Na}^{+} / \mathrm{K}^{+}$buffer $(\mathrm{pH}$ 7.4). The mixture was preincubated for $5 \mathrm{~min}$ at $37^{\circ} \mathrm{C}$. The reaction was performed at $37^{\circ} \mathrm{C}$ by shaking and started by the addition of $80 \mathrm{mM}$ testosterone (dissolved in methanol). After $10 \mathrm{~min}$, the reaction was stopped with $5 \mathrm{~mL}$ ice-cold dichloromethane and $9 \mathrm{nmol}$ corticosterone (internal standard) in methanol. After $1 \mathrm{~min}$ of mixing, phases were separated by centrifugation at $2000 \times g$ for $10 \mathrm{~min}$ and the aqueous phase was extracted once more with $2 \mathrm{~mL}$ dichloromethane. The organic phase was extracted with $2 \mathrm{~mL} 0.02 \mathrm{~N} \mathrm{NaOH}$ to remove lipid constituents, dried over anhydrous sodium sulphate and transferred to a small tube. Dichloromethane was evaporated at $37^{\circ} \mathrm{C}$ under nitrogen and the dried samples stored at $-20^{\circ} \mathrm{C}$. The samples were dissolved in $100 \mu \mathrm{L}$ methanol and analysed by HPLC [37].

Chromatographic separations were performed using a system consisting of a high-pressure pump (Waters Model 600E, Multisolvent Delivery System), a sample injection valve (Rheodyne Model 7121, California, USA) with a $20 \mu \mathrm{L}$ sample loop and an ultraviolet (UV) detector $(254 \mathrm{~nm}$, Waters Model 486, Tunable Absorbance Detector) connected to an integrator (Millennium 2010, Chromatography Manager). For reversed-phase separation of metabolites, a NOVA-PAK C18 analytical column ( $60 \AA, 4 \mathrm{~mm}, 3.9 \mathrm{~mm} \times 150 \mathrm{~mm}$, Waters) was used for the stationary phase. The mobile phase consisted of a mixture of solvent A $(7.5 \%(\mathrm{v} / \mathrm{v})$ tetrahydrofuran in water) and solvent B (7.5\% (v/v) tetrahydrofuran and $60 \%$

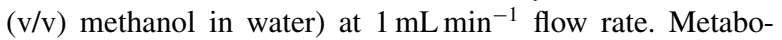
lite separation was performed by a gradient from $30 \%$ to $100 \%(\mathrm{v} / \mathrm{v})$ of solvent B over $30 \mathrm{~min}$. The eluent was monitored at $254 \mathrm{~nm}$ and the area under the absorption band was integrated. The concentration of metabolites was determined by the ratio between respective metabolite peak areas and corticosterone (the internal standard), and the calibration curves were obtained with synthetic testosterone derivatives $[38,39]$.

\subsection{Protein concentration}

Protein concentration was determined according to the method described by Lowry et al. [40] as revised by Bailey [41], using bovine serum albumin as a standard. Samples were diluted at least 200 times to provide a suitable protein concentration.

\subsection{EPR radical-probe technique}

Microsomes were incubated at $37^{\circ} \mathrm{C}$ directly in standard EPR capillary tubes in $0.01 \mathrm{M} \mathrm{Na}^{+} / \mathrm{K}^{+}$phosphate buffer $(\mathrm{pH}$ 7.4) in the presence of $1 \mathrm{mM}$ NADPH and a $0.5 \mathrm{mM}$ hydroxylamine probe, bis(1-hydroxy-2,2,6,6-tetramethyl-4piperidinyl)decandioate, synthesized as previously described [42]. After mixing, the samples were immediately placed within the spectrometer's EPR cavity. The nitroxide radicals 
generated by reaction of the probe with the ROS present in the samples were then measured by EPR on a Bruker ESP 300 spectrometer equipped with an NMR gaussmeter for field calibration, a Bruker ER 033M FF-lock and a Hewlett-Packard 5350B microwave frequency counter for the determination of the $g$-factor. Spectra were recorded using the following instrumental settings: modulation amplitude $=1.0 \mathrm{G}$; conversion time $=163.84 \mathrm{~ms}$; time constant $=163.84 \mathrm{~ms}$; receiver gain $=1.0 \mathrm{E} 5$; microwave power $=6.3 \mathrm{~mW}$. The intensity of the first spectral line of the nitroxide was used to obtain the instantaneous concentration of ROS in the microsomal sample, after calibration of the spectrometer response with a standard solution of TEMPO-choline in water, using an artificial ruby crystal as internal standard. The rate of ROS generation was obtained by recording the EPR spectra of each sample at regular time intervals and by plotting the calibrated EPR intensity versus time. As the EPR signal grew linearly with time (following apparent zero-order kinetics) the slope of the straight line was taken as a measure of the relative rate of ROS generation.

\subsection{Micronucleus test}

The MN test was performed on circulating erythrocytes as detailed previously [43] from a subset of the same $C$. carpio fish previously described. Erythrocytes were obtained at 0,10 and 20 days after exposure to the different types of disinfected water.

Blood samples from seven fish were studied per experimental point. Heparinized (sodium heparin, CLARISCO ${ }^{\circledR}$, Schwarz Pharma S.p.A., Milano, Italy) whole blood smears were done immediately after sacrifice, fixed with absolute ethanol for $20 \mathrm{~min}$, then Feulgen stained (1 h in Shiff reagent, Merck, Germany) after 15 min of acid hydrolysis at $60^{\circ} \mathrm{C}$ in $1 \mathrm{~N}$ $\mathrm{HCl}$ and mounted with dissolved polystyrene in xylene (DPX, Fluka, Milano, Italy).

For each sample, 20,000 erythrocytes were analysed under a light microscope $(1000 \times$ magnification). Only nucleated erythrocytes with an intact cellular and nuclear envelope were scored. Rounded particles not larger than $1 / 5$ of the main nucleus and without any connection to the nucleus were accepted as MN [10]. The scoring criteria were given in detail previously $[9,10,43]$.

\subsection{Statistics and computer analysis}

Statistical analysis for the monooxygenase activities was performed using the Wilcoxon's rank method, as reported by Box and Hunter [44]. The software used was Sigma Plot 5.0 and Windows XP run on a Pentium IV 4 IBM-compatible computer. Non-parametric tests (Kruskal-Wallis ANOVA and two-tailed Mann-Whitney) were performed on MN induction, for control data evaluation among the different sampling times, as well as pairwise comparison of $\mathrm{MN}$ frequencies observed at each experimental point of the exposed groups with the corresponding (exposure time) control.

\section{Results}

\subsection{Mixed function monooxygenases}

\subsubsection{Specific biomarkers}

The exposure of $C$. carpio fish for 10 or 20 consecutive days with the studied disinfectants resulted in no substantial difference in either the absolute or relative weights of the livers between exposed fish and controls (data not shown). Exposure did variably perturb several liver CYP-metabolizing enzymes (Table 1). In males, the exposure to water containing the PAA disinfectant significantly increased $(p<0.01)$ PROD activity 2.7 -fold after 10 days (ET10) and 3.6-fold after 20 days (ET20). EROD activity was increased 56.7-fold at ET10 and 3.6fold at ET20. In contrast, $\mathrm{NaClO}$ significantly decreased $(p<0.01)$ APND activity (almost a $40 \%$ loss at ET20), PNH activity (about a 90\% loss at ET20) and MROD activity (up to a $49 \%$ loss at ET10). The $\mathrm{NaClO}$ disinfectant significantly induced $(p<0.01)$ PROD $(5.7-$ and 3.7-fold, at ET10 and ET20, respectively) and, particularly, EROD activity (23.1- and 3.6-fold, at ET10 and ET20, respectively), while PNH activity was strongly reduced (about a 90\% loss at ET20, $p<0.01$ ). The $\mathrm{ClO}_{2}$ disinfectant significantly $(p<0.01)$ induced PROD activity (3.2-fold, after 20 days of exposure) and EROD activity (2.5- and 3.7-fold, at ET10 and ET20, respectively), but markedly decreased $(p<0.01)$ PNH (about a 90\% loss at ET20) and MROD activities (almost a $88 \%$ loss at ET20).

In female carp (Table 1), PAA significantly induced (all $p<0.01$ ) PROD (3.1- and 2.1-fold, at the ET10 and ET20, respectively), EROD (8.3-fold, at ET10) and MROD (4.1-fold, at ET10) activities, but markedly decreased (all $p<0.01$ ) APND (up to a 54\% loss at ET20), PNH (up to a 59\% loss at ET10) and EROD (up to a $85 \%$ loss at ET20) activities. $\mathrm{NaClO}$ was able to significantly (all $p<0.01$ ) induce some monooxygenases such as PROD (about two-fold, at ET20) and EROD (17.8fold, at ET10) activities, but decreased (all $p<0.01$ ) APND (up to $48 \%$ loss at ET10), PNH (up to a $45 \%$ and $47 \%$ loss at the ET10 and ET20, respectively) and especially EROD (up to a $85 \%$ loss at the ET20) activity. $\mathrm{ClO}_{2}$ significantly (all $p<0.01$ ) induced PROD (5.4fold, at ET20), EROD (2.4-fold, at ET10) and MROD (7.4-fold, at ET20) activities, but decreased (all $p<0.01$ ) PNH (almost a $41 \%$ loss at ET10) and EROD (about a $60 \%$ loss at ET20) activities.

\subsubsection{Testosterone hydroxylases}

In male liver (Table 2), no significant increase in the hydroxylation of testosterone was recorded for any 
Table 1

Carcinogen-metabolizing enzymes in hepatic microsomes of Cyprinus carpio fish exposed to PAA, $\mathrm{NaClO}$ and $\mathrm{ClO}_{2}$

\begin{tabular}{|c|c|c|c|c|c|c|c|c|}
\hline \multirow[t]{2}{*}{ Linked monooxygenases } & \multicolumn{2}{|l|}{ None } & \multicolumn{2}{|l|}{ PAA } & \multicolumn{2}{|l|}{$\mathrm{NaClO}$} & \multicolumn{2}{|l|}{$\mathrm{ClO}_{2}$} \\
\hline & $\mathrm{M}$ & $\mathrm{F}$ & $\mathrm{M}$ & $\mathrm{F}$ & $\mathrm{M}$ & $\mathrm{F}$ & $M$ & $\mathrm{~F}$ \\
\hline \multicolumn{9}{|l|}{ Exposure time (10 days) } \\
\hline $\begin{array}{l}\text { Aminopyrine } N \text {-demethylase } \\
\quad\left(\mathrm{nmol} \mathrm{mg}{ }^{-1} \min ^{-1}\right)\end{array}$ & $1.84 \pm 0.16$ & $1.81 \pm 0.09$ & $1.89 \pm 0.12$ & $1.86 \pm 0.17$ & $1.64 \pm 0.17$ & $0.94 \pm 0.07^{* *}$ & $2.17 \pm 0.09^{*}$ & $1.84 \pm 0.13$ \\
\hline $\begin{array}{l}p \text {-Nitrophenol hydroxylase } \\
\left(\mathrm{nmol} \mathrm{mg} \mathrm{min}^{-1} \mathrm{~min}^{-1}\right.\end{array}$ & $0.10 \pm 0.01$ & $0.22 \pm 0.01$ & $0.09 \pm 0.01$ & $0.09 \pm 0.01^{* *}$ & $0.11 \pm 0.01$ & $0.12 \pm 0.01^{* *}$ & $0.08 \pm 0.01$ & $0.13 \pm 0.01^{* *}$ \\
\hline $\begin{array}{l}\text { Pentoxyresorufin } O \text {-dealkylase } \\
\quad\left(\mathrm{pmol} \mathrm{mg}^{-1} \mathrm{~min}^{-1}\right)\end{array}$ & $0.09 \pm 0.01$ & $0.16 \pm 0.01$ & $0.24 \pm 0.02^{* *}$ & $0.49 \pm 0.05^{* *}$ & $0.51 \pm 0.04^{* *}$ & $0.11 \pm 0.01$ & $0.13 \pm 0.01^{*}$ & $0.22 \pm 0.01$ \\
\hline $\begin{array}{l}\text { Ethoxyresorufin } O \text {-deethylase } \\
\quad\left(\mathrm{pmol} \mathrm{mg}^{-1} \mathrm{~min}^{-1}\right)\end{array}$ & $0.19 \pm 0.01$ & $0.09 \pm 0.01$ & $10.76 \pm 0.71^{* *}$ & $0.75 \pm 0.07^{* *}$ & $4.38 \pm 0.18^{* *}$ & $1.60 \pm 0.10^{* *}$ & $0.47 \pm 0.02^{* *}$ & $0.22 \pm 0.02^{* *}$ \\
\hline $\begin{array}{l}\text { Methoxyresorufin } \\
O \text {-demethylase } \\
(\text { pmol mg } \\
\end{array}$ & $0.73 \pm 0.02$ & $0.29 \pm 0.03$ & $0.37 \pm 0.01^{* *}$ & $1.18 \pm 0.09^{* *}$ & $0.53 \pm 0.01^{* *}$ & $0.45 \pm 0.03^{* *}$ & $0.59 \pm 0.05^{* *}$ & $0.27 \pm 0.02^{* *}$ \\
\hline \multicolumn{9}{|l|}{ Exposure time (20 days) } \\
\hline $\begin{array}{l}\text { Aminopyrine } N \text {-demethylase } \\
\quad\left(\mathrm{nmol} \mathrm{mg} \mathrm{min}^{-1} \mathrm{~min}^{-1}\right)\end{array}$ & $2.03 \pm 0.19$ & $2.99 \pm 0.20$ & $1.24 \pm 0.07^{* * *}$ & $1.37 \pm 0.14^{* *}$ & $1.65 \pm 0.10^{* *}$ & $2.21 \pm 0.21^{*}$ & $2.67 \pm 0.29^{*}$ & $2.56 \pm 0.21$ \\
\hline $\begin{array}{l}p \text {-Nitrophenol hydroxylase } \\
(\mathrm{nmol} \mathrm{mg} \\
\left.-1 \mathrm{~min}^{-1}\right)\end{array}$ & $0.09 \pm 0.01$ & $0.17 \pm 0.01$ & $0.01 \pm 0.002^{* *}$ & $0.16 \pm 0.01$ & $0.01 \pm 0.002^{* *}$ & $0.09 \pm 0.01^{* *}$ & $0.06 \pm 0.008^{* *}$ & $0.14 \pm 0.01$ \\
\hline $\begin{array}{l}\text { Pentoxyresorufin } O \text {-dealkylase } \\
\quad\left(\mathrm{pmol} \mathrm{mg}^{-1} \mathrm{~min}^{-1}\right)\end{array}$ & $0.09 \pm 0.01$ & $0.16 \pm 0.01$ & $0.32 \pm 0.02^{* *}$ & $0.33 \pm 0.03^{* *}$ & $0.33 \pm 0.01^{* *}$ & $0.31 \pm 0.02^{* *}$ & $0.29 \pm 0.01^{* *}$ & $0.86 \pm 0.08^{* *}$ \\
\hline $\begin{array}{l}\text { Ethoxyresorufin } O \text {-deethylase } \\
\quad\left(\mathrm{pmol} \mathrm{mg}^{-1} \mathrm{~min}^{-1}\right)\end{array}$ & $0.19 \pm 0.01$ & $1.67 \pm 0.17$ & $0.68 \pm 0.06^{* *}$ & $0.25 \pm 0.02^{* *}$ & $0.68 \pm 0.07^{* *}$ & $0.24 \pm 0.02^{* * *}$ & $0.70 \pm 0.06^{* *}$ & $0.67 \pm 0.05^{* *}$ \\
\hline $\begin{array}{l}\text { Methoxyresorufin } \\
O \text {-demethylase } \\
\left(\mathrm{pmol} \mathrm{mg}^{-1} \mathrm{~min}^{-1}\right)\end{array}$ & $0.73 \pm 0.02$ & $0.30 \pm 0.03$ & $0.73 \pm 0.08^{* *}$ & $0.54 \pm 0.06^{*}$ & $1.29 \pm 0.13^{* *}$ & $0.42 \pm 0.04$ & $0.09 \pm 0.01^{* *}$ & $2.22 \pm 0.19^{* *}$ \\
\hline
\end{tabular}

Each value represents the mean \pm S.D. of six enzymatic experiments on six different fish for each studied group. See Section 2 for details and experimental procedures. ${ }^{*} p<0.05,{ }^{* *} p<0.01$, significant differences between treated groups and their respective controls, using the Wilcoxon's rank method. 
Table 2

Testosterone hydroxylase in liver microsomes of $C$. carpio fish exposed to PAA, $\mathrm{NaClO}$ or $\mathrm{ClO}_{2}$

\begin{tabular}{|c|c|c|c|c|c|c|c|c|}
\hline \multirow[t]{2}{*}{ Linked monooxygenases } & \multicolumn{2}{|l|}{ None } & \multicolumn{2}{|l|}{ PAA } & \multicolumn{2}{|l|}{$\mathrm{NaClO}$} & \multicolumn{2}{|l|}{$\mathrm{ClO}_{2}$} \\
\hline & M & $\mathrm{F}$ & $\mathrm{M}$ & $\mathrm{F}$ & M & $\mathrm{F}$ & M & F \\
\hline \multicolumn{9}{|l|}{ Exposure time (10 days) } \\
\hline $6 \alpha$-Hydroxytestosterone $\left(\mathrm{pmol} \mathrm{mg}^{-1} \mathrm{~min}^{-1}\right)$ & $3.56 \pm 0.29$ & $3.35 \pm 0.15$ & $2.06 \pm 0.13^{* *}$ & $5.41 \pm 0.11^{* *}$ & $4.76 \pm 0.51^{* *}$ & $2.62 \pm 0.05^{*}$ & $2.36 \pm 0.24^{* *}$ & $3.16 \pm 0.12$ \\
\hline $7 \alpha$-Hydroxytestosterone $\left(\mathrm{pmol} \mathrm{mg}^{-1} \mathrm{~min}^{-1}\right)$ & $2.43 \pm 0.08$ & $3.24 \pm 0.02$ & $2.45 \pm 0.21$ & $2.48 \pm 0.25^{*}$ & $2.98 \pm 0.28^{*}$ & $1.64 \pm 0.15^{* *}$ & $2.52 \pm 0.08$ & $1.97 \pm 0.18^{* * *}$ \\
\hline $6 \beta$-Hydroxytestosterone $\left(\mathrm{nmol} \mathrm{mg}^{-1} \mathrm{~min}^{-1}\right)$ & $11.65 \pm 0.08$ & $8.20 \pm 0.40$ & $5.81 \pm 0.13^{* *}$ & $10.27 \pm 0.40^{* *}$ & $7.15 \pm 0.68^{* *}$ & $4.77 \pm 0.05^{* *}$ & $7.40 \pm 0.32^{* *}$ & $6.49 \pm 0.12 *^{*}$ \\
\hline $16 \alpha$-Hydroxytestosterone $\left(\mathrm{nmol} \mathrm{mg}^{-1} \mathrm{~min}^{-1}\right)$ & $1.17 \pm 0.12$ & $2.01 \pm 0.18$ & $0.88 \pm 0.09^{*}$ & $2.53 \pm 0.28$ & $0.72 \pm 0.06^{* *}$ & $0.70 \pm 0.08^{* *}$ & $0.59 \pm 0.06^{* *}$ & $0.92 \pm 0.10^{* *}$ \\
\hline $16 \beta$-Hydroxytestosterone $\left(\mathrm{pmol} \mathrm{mg}^{-1} \mathrm{~min}^{-1}\right)$ & $6.13 \pm 0.07$ & $1.13 \pm 0.09$ & $2.24 \pm 0.09^{* *}$ & $1.85 \pm 0.12^{* *}$ & $3.37 \pm 0.08^{* *}$ & $2.46 \pm 0.08^{* *}$ & $0.90 \pm 0.06^{* *}$ & $1.41 \pm 0.07^{*}$ \\
\hline $2 \alpha$-Hydroxytestosterone $\left(\mathrm{nmol} \mathrm{mg}^{-1} \mathrm{~min}^{-1}\right)$ & $1.53 \pm 0.14$ & $0.09 \pm 0.01$ & $1.25 \pm 0.10$ & $0.86 \pm 0.06^{* *}$ & $2.36 \pm 0.18^{* *}$ & $0.16 \pm 0.01^{* *}$ & $1.00 \pm 0.08^{* *}$ & $0.41 \pm 0.02^{* *}$ \\
\hline $2 \beta$-Hydroxytestosterone $\left(\mathrm{pmol} \mathrm{mg}^{-1} \mathrm{~min}^{-1}\right)$ & $10.45 \pm 0.50$ & $0.58 \pm 0.06$ & $4.98 \pm 0.25^{* *}$ & $0.67 \pm 0.06$ & $9.00 \pm 0.88$ & $1.74 \pm 0.09^{* *}$ & $9.07 \pm 0.72$ & $1.05 \pm 0.05^{* *}$ \\
\hline 4-Androsten-3,17-dione $\left(\mathrm{nmol} \mathrm{mg}{ }^{-1} \mathrm{~min}^{-1}\right)$ & $0.72 \pm 0.05$ & $0.63 \pm 0.03$ & $0.44 \pm 0.03^{* *}$ & $0.80 \pm 0.02^{* *}$ & $0.48 \pm 0.02^{* *}$ & $0.31 \pm 0.01^{* *}$ & $0.49 \pm 0.03^{* *}$ & $0.38 \pm 0.01^{* *}$ \\
\hline \multicolumn{9}{|l|}{ Exposure time (20 days) } \\
\hline $6 \alpha$-Hydroxytestosterone $\left(\mathrm{pmol} \mathrm{mg}^{-1} \mathrm{~min}^{-1}\right)$ & $3.77 \pm 0.29$ & $3.22 \pm 0.29$ & $2.58 \pm 0.29^{* *}$ & $2.94 \pm 0.21^{* *}$ & $4.21 \pm 0.30$ & $4.53 \pm 0.35^{* *}$ & $4.87 \pm 0.16^{*}$ & $4.71 \pm 0.33^{* *}$ \\
\hline $7 \alpha$-Hydroxytestosterone $\left(\mathrm{pmol} \mathrm{mg}^{-1} \mathrm{~min}^{-1}\right)$ & $2.91 \pm 0.26$ & $3.24 \pm 0.26$ & $1.60 \pm 0.07^{* *}$ & $2.97 \pm 0.19$ & $2.13 \pm 0.20^{* *}$ & $3.99 \pm 0.32$ & $4.08 \pm 0.35^{* *}$ & $2.84 \pm 0.23$ \\
\hline $6 \beta$-Hydroxytestosterone $\left(\mathrm{nmol} \mathrm{mg}^{-1} \mathrm{~min}^{-1}\right)$ & $7.06 \pm 0.31$ & $8.06 \pm 0.64$ & $6.87 \pm 0.07$ & $6.18 \pm 0.47^{* *}$ & $5.51 \pm 0.14^{* *}$ & $9.98 \pm 0.72$ & $9.83 \pm 0.63^{* *}$ & $9.03 \pm 0.65$ \\
\hline $16 \alpha$-Hydroxytestosterone $\left(\mathrm{nmol} \mathrm{mg}^{-1} \mathrm{~min}^{-1}\right)$ & $1.29 \pm 0.10$ & $1.25 \pm 0.09$ & $1.03 \pm 0.08^{*}$ & $1.77 \pm 0.06^{*}$ & $1.14 \pm 0.07$ & $1.96 \pm 0.08^{* *}$ & $1.34 \pm 0.11$ & $1.75 \pm 0.08^{*}$ \\
\hline $16 \beta$-Hydroxytestosterone $\left(\mathrm{pmol} \mathrm{mg}^{-1} \mathrm{~min}^{-1}\right)$ & $5.79 \pm 0.38$ & $7.48 \pm 0.54$ & $3.57 \pm 0.29^{* *}$ & $2.40 \pm 0.12^{* *}$ & $6.18 \pm 0.39$ & $5.32 \pm 0.37^{* *}$ & $9.31 \pm 0.48^{* *}$ & $10.22 \pm 0.85^{* *}$ \\
\hline $2 \alpha$-Hydroxytestosterone $\left(\mathrm{nmol} \mathrm{mg}^{-1} \mathrm{~min}^{-1}\right)$ & $1.23 \pm 0.10$ & $1.00 \pm 0.06$ & $1.14 \pm 0.09$ & $1.71 \pm 0.10^{* *}$ & $0.89 \pm 0.06^{* *}$ & $1.39 \pm 0.09^{* *}$ & $1.02 \pm 0.07^{*}$ & $1.63 \pm 0.09^{* *}$ \\
\hline $2 \beta$-Hydroxytestosterone $\left(\mathrm{pmol} \mathrm{mg}^{-1} \mathrm{~min}^{-1}\right)$ & $10.45 \pm 0.65$ & $0.62 \pm 0.04$ & $1.72 \pm 0.16^{* *}$ & $1.14 \pm 0.09^{* *}$ & $1.18 \pm 0.10^{* *}$ & $0.64 \pm 0.05$ & $3.14 \pm 0.24^{* *}$ & $1.42 \pm 0.09^{* * *}$ \\
\hline 4-Androsten-3,17-dione $\left(\mathrm{nmol} \mathrm{mg} \mathrm{min}^{-1} \mathrm{~min}^{-1}\right)$ & $0.62 \pm 0.05$ & $0.54 \pm 0.04$ & $0.42 \pm 0.01^{* *}$ & $0.52 \pm 0.05$ & $0.48 \pm 0.01^{*}$ & $0.69 \pm 0.05$ & $0.69 \pm 0.04$ & $0.65 \pm 0.04^{*}$ \\
\hline
\end{tabular}

Each value represents the mean \pm S.D. of six enzymatic experiments on six different fish for each studied group. See Section 2 for details and experimental procedures. ${ }^{*} p<0.05,{ }^{* *} p<0.01$, significant differences between treated groups and their respective controls, using the Wilcoxon's rank method. 
disinfectant compared to controls at the different time intervals tested. However, PAA significantly decreased testosterone hydroxylation $(p<0.01)$ in positions $6 \alpha$ (up to a $42 \%$ loss at ET10), $7 \alpha$ (up to a $45 \%$ loss at ET20), $6 \beta$ (up to a $50 \%$ loss at ET10), $16 \beta$ (about a $64 \%$ loss at ET10 and a $40 \%$ loss at ET20) and $2 \beta$ (about a 52\% loss at ET10 and a $84 \%$ loss at ET20). Also reduced by PAA was the 4-androsten-3,17-dione oxidase either ET10 (almost a $39 \%$ loss, $p<0.01$ ) or at ET20 (almost a $32 \%$ loss, $p<0.01)$. Similarly, as seen in Table 2 , $\mathrm{NaClO}$ significantly decreased $(p<0.01)$ hydroxylation of testosterone at positions $6 \beta, 16 \alpha, 16 \beta$ and $2 \beta$ positions. A significant decrease $(p<0.01)$ in position 17 hydroxylation of testosterone was also observed at ET10 (up to a $33 \%$ loss, $p<0.01$ ) or ET20 (about a $23 \%$ loss, $p<0.05)$ with $\mathrm{NaClO}$. In addition, $\mathrm{ClO}_{2}$ significantly decreased testosterone hydroxylation $(p<0.01)$ in positions $6 \beta, 16 \alpha$ and $2 \beta$. The 4 -androsten-3,17-dionelinked monooxygenase was markedly reduced by $\mathrm{ClO}_{2}$ (about a $32 \%$ loss, $p<0.01$ ) after 10 days of exposure only.

In the liver of females (Table 2), the disinfectant PAA was able to significantly increase $(p<0.01)$ the hydroxylation of testosterone in positions $2 \alpha$, but decreased hydroxylation at the $16 \alpha$ position. Minor modifications for the other hydroxylations were observed. $\mathrm{NaClO}$ increased the hydroxylation $(p<0.01)$ in the $16 \beta$ and $2 \beta$ positions. It decreased the hydroxylation $(p<0.01)$ at the $7 \alpha, 6 \beta$ and $16 \alpha$ positions. 4-Androsten-3,17-dioneassociated monooxygenase was also strongly reduced (about a $51 \%$ loss at ET10) by $\mathrm{NaClO} . \mathrm{ClO}_{2}$ increased the hydroxylation $(p<0.01)$ at the $2 \alpha$ and $2 \beta$ positions, and decreased the hydroxylation $(p<0.01)$ at the $7 \alpha$ and $16 \alpha$ positions. 4-Androsten-3,17-dione-supported oxidase was reduced about $40 \%$ after 10 days of exposure to $\mathrm{ClO}_{2}$.

\subsection{EPR radical-probe technique}

The relative rate of ROS generation by liver microsomes obtained from control and 10-day-exposed $C$. carpio to $\mathrm{NaClO}, \mathrm{ClO}_{2}$ or PAA were obtained, using the EPR radical-probe technique, by monitoring the time evolution of the first EPR spectral line of the nitroxide radical generated by ROS-mediated oxidation of the hydroxylamine probe [42]. The results summarized in Table 3 indicate that fish exposed to the test compounds generally showed significantly higher rates of ROS generation as compared to non-exposed controls $(p<0.05)$. Differences were also observed among the disinfectants, with $\mathrm{NaClO}$ inducing twice the rate of ROS generation compared to PAA $(p<0.05)$.
Table 3

Relative rate (average controls $=1.0$ ) of ROS production in liver microsomes prepared from $C$. carpio after 10 days of exposure to water disinfected with PAA, $\mathrm{NaClO}$ or $\mathrm{ClO}_{2}$

\begin{tabular}{ll}
\hline Controls & $1.0 \pm 0.5$ \\
PAA & $1.7 \pm 0.4^{\mathrm{a}}$ \\
$\mathrm{NaClO}$ & $3.8 \pm 0.8^{\mathrm{a}}$ \\
$\mathrm{ClO}_{2}$ & $2.5 \pm 0.7^{\mathrm{a}}$ \\
\hline
\end{tabular}

Each value represents the mean \pm S.D of six spectroscopic experiments on six different fish for each studied group.

a Values were significantly different from control $(p<0.05$; Mann-Whitney test).

Table 4

Micronucleus frequencies (mean values per 20,000 cells \pm S.E.) in $C$. carpio erythrocytes (seven individual fish per data point) after exposure to water disinfected with $\mathrm{PAA}, \mathrm{NaClO}$ and $\mathrm{ClO}_{2}$

\begin{tabular}{llccc}
\hline & Controls & PAA & $\mathrm{NaClO}$ & $\mathrm{ClO}_{2}$ \\
\hline $\mathrm{T} 0$ & $0.43 \pm 0.20$ & - & - & - \\
$\mathrm{T} 10$ & $0.29 \pm 0.29$ & $0.83 \pm 0.40^{\mathrm{a}}$ & $1.71 \pm 0.89$ & $2.14 \pm 0.88^{*}$ \\
$\mathrm{~T} 20$ & $0.25 \pm 0.25^{\mathrm{b}}$ & $0.43 \pm 0.30$ & $1.29 \pm 0.52$ & $1.14 \pm 0.34$ \\
\hline
\end{tabular}

${ }^{*} p<0.05$, significant difference between treated and control group (Mann-Whitney test).

${ }^{a}$ Only six individual fish were tested at T10.

b Only four individual fish were tested at T20.

\subsection{Micronucleus test}

The mean MN frequencies in 20,000 cells ( \pm S.E.) are presented in Table 4. Generally, an increasing trend in MN frequencies was observed in erythrocytes of fish exposed to water treated with $\mathrm{NaClO}$ and $\mathrm{ClO}_{2}$ at both ET10 and ET20. When comparing each experimental point with the corresponding control, significant $(p<0.05)$ values were found for $\mathrm{ClO}_{2}$ at ET10. There were no significant variations in control values obtained from each experiment, and $\mathrm{MN}$ frequencies were not significantly elevated in fish exposed to water treated with PAA.

\section{Discussion}

To the best of our knowledge for the first time we report here the effects on phase-I xenobiotic metabolizing enzymes in $C$. carpio of exposure to water disinfected with $\mathrm{NaClO}, \mathrm{ClO}_{2}$ and PAA. The concentrations of disinfectants employed in this investigation are the actual concentrations used for surface water treatment. Testosterone (as a multi-bioprobe) and individual specific substrates to different CYPs were used to study oxidative reactions. EPR spectroscopy, coupled with a spin-trapping technique, was employed to measure the 
level of ROS that are linked to the CYP-dependent cellular machinery. The in vivo DNA-damaging potential of water treated by the three disinfectants was also assessed in circulating erythrocytes of $C$. carpio using the MN assay. The MN assay in fish is a useful tool for detecting clastogenic substances in aqueous media. Several studies have shown that erythrocytes of fish exhibit an increased $\mathrm{MN}$ frequency following exposure to mutagenic pollutants [43,45-47]. Micronuclei are formed by condensation of chromosomal fragments or whole chromosomes that are not included in the main nucleus following anaphase of the dividing erythropoietic stem cells in the cephalic kidney. The time interval between their initial induction and their detection in the circulating erythrocyte cell population is rather long. This time depends on the cell-cycle duration, the number of the occurring mitotic events, and the duration of their residency in the kidney marrow needed for cell differentiation and maturation. Once micronucleated erythrocytes are produced, they persist in the red blood cell population until their removal.

In our study, we observed both induction and suppression of the different CYP450 isoenzymes that were studied following water treatment. For example, the PAA disinfectant was found to markedly induce several CYP-associated oxidative reactions, with different magnitudes, in both sexes of fish. A notable suppression of several CYP-linked microsomal mixed function monooxygenases was also observed for all disinfectants studied. This suggests that the three chemicals studied may affect the CYP profile in a rather complex manner. As such, they may exercise either an antagonistic or an agonistic effect or, in some cases, even a synergistic effect. The effects are determined by the type of the disinfectant, the sex of the fish, as well as the time of exposure to that particular chemical and its by-products in relation to the specific CYP isoenzyme evaluated. In male fish, for example, CYP1A1-linked ethoxyresorufin $O$-deethylation was the most affected CYP, with an increase of up to 57-fold after 10 days of exposure with PAA. A similar elevated response was also observed in males after 10 days of exposure to $\mathrm{NaClO}$, where an increase of up to 23-fold for EROD activity was detected. In contrast, females had only minor changes in CYPs after exposure to PAA or $\mathrm{NaClO}$. Females also seem to be less responsive to the modulating effects of $\mathrm{ClO}_{2}$, as exemplified by the modest induction of CYP1A2linked $O$-demethylation of methoxyresorufin after 20 days of exposure. The three disinfectants studied may thus affect different CYP isoforms differently depending on the time of exposure and the sex of the exposed fish.
Using single probes specific to different CYP isoforms, the male $C$. carpio fish seem to be the most responsive to the CYP-inducing effects of the tested disinfectants, as compared to females. Using the regioand stereo-selective hydroxylation of testosterone as a multi-probe, however, we found that CYP induction was only observed in the livers of females. This difference can be explained by the different CYP isoforms measured by the different probes. For example, in females, the disinfectant PAA was able to increase testosterone $2 \alpha$-hydroxylation (up to 9.6-fold) after 10 days of exposure, and there were minor increases in testosterone hydroxylation for $\mathrm{NaClO}$ and $\mathrm{ClO}_{2}$ (Table 2). In females, some suppressions were also registered, such as those with PAA after 10 days of exposure (up to a $68 \%$ loss) for hydroxylation in the $16 \alpha$ position, as well as by $\mathrm{ClO}_{2}$ and $\mathrm{NaClO}$ (up to a $54 \%$ and a $65 \%$ loss, respectively) for $16 \alpha$-hydroxylation. In males, a drastic, generalized monooxygenase suppression was clearly recorded, mostly in testosterone $16 \beta$-hydroxylase $(64 \%$ loss) by PAA after 10 days of exposure, and in testosterone $2 \beta$-hydroxylase ( $89 \%$ and $70 \%$ loss) by $\mathrm{NaClO}$ and $\mathrm{ClO}_{2}$, respectively, after 20 days of exposure. These findings indicate that all disinfectants markedly affect oxidative metabolism in a sex-dependent manner.

A significant increase in the rate of ROS generation was observed, regardless of the sex of the fish, after 10 days of exposure to all three disinfectants. Clearly, this is the result of the relevant perturbation of the many CYP isoforms that are involved in ROS formation, particularly superoxide. Several decades ago Gillette et al. [47] in 1957 identified the smooth endoplasmic reticulum membrane as an efficient source of ROS. However, it was recently discovered that the regulation of various $C Y P$ isoforms (including CYP1A, CYP2B, CYP3A, CYP4A, and virtually any CYP) generate very large amounts of ROS [48-50]. Induction of ROS generation by any of the disinfectants (from $+70 \%$ for PAA to $+280 \%$ for $\mathrm{NaClO}$ ) have some importance, yet these increases are not as massive as variations observed in previous investigations in different animal models treated with other xenobiotics or with other environmental pollutants [42,51-53]. This possibly reflects the very complex activation/suppression pattern observed herein for the many enzymatic activities directly or indirectly involved in ROS generation.

Our data from the $\mathrm{MN}$ test indicate that exposure to surface waters of Trasmene lake disinfected with $\mathrm{NaClO}$ moderately induced $\mathrm{MN}$, while the chlorinated disinfectant $\mathrm{ClO}_{2}$ was associated with a significant mutagenic response. In contrast, it seems that exposure to PAA does 
not induce a significant mutagenic effect. The negative result with PAA in the MN test may provide additional evidence for the lack of a mutagenic effect of this disinfectant, at least in this biological system. This is to some extent paralleled by the lower induction of ROS recorded for PAA as compared to the chlorinated disinfectants. The large amount of ROS generated by CYP induction following exposure to $\mathrm{NaClO}$ and $\mathrm{ClO}_{2}$ probably contributed to the observed increase in $\mathrm{MN}$ frequencies attributed to these two disinfectants. The mutagenic responses observed after $\mathrm{NaClO}$ and $\mathrm{ClO}_{2}$ exposure are in agreement with those reported in a longitudinal study carried out by Buschini et al. [54] on genotoxic damage (using the comet assay and $\mathrm{MN}$ frequency) induced by these disinfectants. In this study, Buschini et al. [54] observed a positive genotoxic response after treatment with all chlorinated disinfectants, as indicated by both primary DNA damage and mutagenicity induction.

All three disinfectants tested, were capable of markedly perturbing fish microsomal metabolism, in terms of both induction and suppression of various phase-I catalyzed oxidative reactions. In contrast, only $\mathrm{ClO}_{2}$ was able to significantly induce an increase in $\mathrm{MN}$ frequency, while a non-significant six-fold increase was induced by $\mathrm{NaClO}$, in a range between 1.50 and $2.14 \mathrm{MN} / 20,000$ cells. Although the disinfectant PAA apparently failed to directly produce DNA damage, as determined by the MN assay, its ability to up-regulate CYP-dependent metabolism suggests that this compound may possibly still pose a potential hazard through an alternative (non-genotoxic) mechanism. Extrapolating to humans, long-term exposure of individuals to low doses of any of these disinfectants could thus pose an increased carcinogenic risk. This increased risk could be a result of a generalized increase in bioactivation of ubiquitous pro-mutagens/pro-carcinogens, which could lead to a saturation of the enzymatic apparatus involved in DNA repair, and/or increased generation of ROS (linked to CYP induction) [27].

In summary, our data suggest that the use of chlorinated disinfectants such as $\mathrm{NaClO}$ and $\mathrm{ClO}_{2}$ could generate harmful OBP mixtures that are able to perturb CYP-mediated reactions and induce oxidative stress. These data may provide an explanation for the results of epidemiological studies linking consumption of treated drinking water to increased incidences of urinary and gastrointestinal cancer $[3,14,16]$. Our data on the relatively new alternative disinfectant PAA suggest that, while this compound seems to have no genotoxic effects (using the MN test), it has a CYP-inducing effect and is able to generate ROS. As such, caution should be exercised before PAA can be proposed as a "safe" substitute to chlorine-based disinfection in waste water treatment processes.

\section{Acknowledgements}

We are grateful to Dr. Marinel M. Ammenheuser for editorial assistance. Financial support from MIUR (Rome) is gratefully acknowledged.

\section{References}

[1] World Health Organization, Revision of the WHO Guidelines for Drinking Water Quality, WHO, Geneva, Switzerland, 1996.

[2] J.J. Rook, Formation of haloforms during chlorination of natural waters, J. Water Treat. Exam. 23 (1974) 234-243.

[3] K.T. Cantor, Drinking water and cancer, Cancer Causes Control 8 (1997) 292-308.

[4] G.A. Boorman, Drinking water disinfection by-products: review and approach to toxicity evaluation, Environ. Health Perspect. 107 (1999) 207-217.

[5] M.A. Pereira, Carcinogenic activity of dichloroacetic acid and trichloroacetic acid in the liver of female B6C3F1 mice, Fund. Appl. Toxicol. 31 (1996) 192-199.

[6] IARC, Re-evaluation of some organic chemicals, hydrazine and hydrogen peroxide, in: Proceedings of the IARC Working Group on the Evaluation of Carcinogenic Risks to Humans, Lyon, France, February 17-24, 1998, IARC Monogr. Eval. Carcinogen. Risks Hum. 71 (Pt 1) (1999) 1-315.

[7] J.R. Meier, H.P. Ringhand, W.E. Coleman, K.M. Schenck, J.W. Munch, R.P. Streicher, W.H. Kaylor, F.C. Kopfler, Mutagenic by-products from chlorination of humic acid, Environ. Health Perpect. 69 (1986) 101-107.

[8] T.H. Hutchinson, A.N. Jha, J.M. Mackay, B.M. Elliot, D.R. Dixon, Assessment of developmental effects, cytotoxicity and genotoxicity in the marine polychaete (Platinereis dumerilii) exposed to disinfected municipal sewage effluents, Mutat. Res. 399 (1998) 97-108.

[9] S. Minissi, E. Ciccotti, M. Rizzoni, Micronucleus test in erythrocytes of Barbus plebenius (Teleostei, Pisces) from two natural environments: a bioassay for the in situ detection of mutagens in freshwater, Mutat. Res. 367 (1996) 245-251.

[10] B. Gustavino, K.A. Scornajenghi, S. Minissi, E. Ciccotti, Micronuclei induced in erythrocytes of Ciprinus carpio by X-rays and colchicine, Mutat. Res. 494 (2001) 151-159.

[11] S. Itoh, D. Ikeda, Y. Toba, H. Sumitomo, Changes of activity inducing chromosomal aberrations and transformations of chlorinated humic acids, Water Res. 35 (2001) 2621-2628.

[12] N.H. Woodruff, J.L. Durant, L.L. Donhoffner, B.W. Penman, C.L. Crespi, Human cell mutagenicity of chlorinated and unchlorinated water and the disinfection by-products, Mutat. Res. 495 (2001) $157-168$.

[13] M. Soffritti, F. Belpoggi, A. Lenzi, C. Maltoni, Results of longterm carcinogenicity studies of chlorine in rats, Ann. NY Acad. Sci. 26 (1997) 189-208.

[14] M. Koivusalo, E. Pukkala, T. Vartiainen, J.J. Jaakkola, T. Hakulinen, Drinking water chlorination and cancer-a historical cohort study in Finland, Cancer Causes Control 8 (1997) 192-200.

[15] I.L. Steffensen, J.E. Paulsen, D. Engeset, L. Kronberg, J. Alexander, The drinking water chlorination by-products 3,4-dichloro-5-hydroxy-2[5H]-furanone (mucochloric acid) and 
3-chloro-4-(dichloromethyl)-5-hydroxy-2[5H]-furanone do not induce preneoplastic or neoplastic intestinal lesions in F344 rats, Balb/ca mice or C57bl/6J-min mice, Pharmacol. Toxicol. 85 (1999) 56-64.

[16] J.B. Klotz, L.A. Pyrch, Neural tube defects and drinking water disinfection by-products, Epidemiology 10 (1999) 383-390.

[17] J. Maki-Paakkanen, H. Komulainen, L. Kronberg, Bacterial and mammalian-cell genotoxicity of mixtures of chlorohydroxyfuranones, by-products of water chlorination, Environ. Mol. Mutagen. 43 (2004) 217-225.

[18] M.J. Hooth, K.S. McDorman, S.D. Hester, M.H. George, L.R. Brooks, A.E. Swank, D.C. Wolf, The carcinogenic response of Tsc2 mutant Long-Evans (Eker) rats to a mixture of drinking water disinfection by-products was less than additive, Toxicol. Sci. 69 (2002) 322-331.

[19] K.S. McDorman, M.J. Hooth, T.B. Starr, D.C. Wolf, Analysis of preneoplastic and neoplastic renal lesions in Tsc2 mutant LongEvans (Eker) rats following exposure to a mixture of drinking water disinfection by-products, Toxicology 187 (2003) 1-12.

[20] H. Komulainen, Experimental cancer studies of chlorinated byproducts, Toxicology 198 (2004) 239-248.

[21] M.G.C. Baldry, M.S. French, D. Slater, The activity of peracetic acid on sewage indicator bacteria and viruses, Water Sci. Technol. 24 (1991) 353-357.

[22] M.G.C. Baldry, A. Cavadore, M.S. French, G. Massa, M.L. Rodrigues, P.F.T. Schirch, T.L. Threadgold, Effluent disinfection in warm climates with peracetic acid, Water Sci. Technol. 31 (1995) 161-164.

[23] F. Lefevre, J.M. Audic, F. Verrand, Peracetic acid disinfection of secondary effluents discharged off coastal sea water, Water Sci. Technol. 25 (1992) 155-164.

[24] S. Monarca, S.D. Richardson, D. Feretti, M. Grottolo, A.D. Thruston, C. Zani, G. Navazio, P. Ragazzo, I. Zerbini, A. Alberti, Mutagenicity and disinfection by-products in surface drinking water disinfected with peracetic acid, Environ. Toxicol. Chem. 21 (2002) 309-318.

[25] M. Kitis, Disinfection of wastewater with peracetic acid: a review, Environ. Int. 30 (1) (2004) 47-55.

[26] M. Paolini, G.L. Biagi, G. Cantelli-Forti, C. Bauer, Further mechanisms of non-genotoxic carcinogenesis, Trends Pharmacol. Sci. 15 (1994) 322-323.

[27] M. Paolini, G. Cantelli-Forti, P. Perocco, G.F. Pedulli, S.Z. AbdelRahman, M.S. Legator, Co-carcinogenic effect of beta-carotene, Nature 398 (1999) 760-761.

[28] B.E. Butterworth, Consideration of both genotoxic and nongenotoxic mechanisms in predicting carcinogenic potential, Mutat. Res. 239 (1990) 117-132.

[29] H.E. Poulsen, S. Loft, Early biochemical markers of effects: enzyme induction, oncogene activation and markers of oxidative damage, Toxicology 101 (1995) 55-64.

[30] B.N. Ames, L.S. Gold, W.C. Willett, The causes and prevention of cancer, Proc. Natl. Acad. Sci. U.S.A. 92 (1995) 5258-5265.

[31] J.E. Klaunig, Y. Xu, J.S. Isenberg, S. Bachowski, K.L. Kolaja, J. Jiang, D.E. Stevenson, E.F. Alborg Jr., The role of oxidative stress in chemical carcinogenesis, Environ. Health Perspect. 106 (Suppl. 1) (1998) 289-295.

[32] A. Kinoshita, H. Wanibuchi, S. Imaoka, M. Ogawa, C. Masuda, K. Morimura, Y. Funae, S. Fukushima, Formation of 8hydroxydeoxyguanosine and cell-cycle arrest in the rat liver via generation of oxidative stress by phenobarbital: association with expression profiles of p21(WAF1/Cip1), cyclin D1 and Ogg1, Carcinogenesis 23 (2002) 341-349.
[33] C. Bauer, C. Corsi, M. Paolini, Stability of microsomal monooxygenases in murine liver $\mathrm{S} 9$ fractions derived from phenobarbital and $\beta$-naphthoflavone induced animals under various long-term conditions of storage, Teratogen. Carcinogen. Mutagen. 14 (1994) $13-22$.

[34] P. Mazel, Fundamentals of Drug Metabolism and Drug Disposition, Wiliams and Wilkins, Baltimore, 1971, pp. 546-550.

[35] T. Nash, Colorimetric estimation of formaldehyde by means of Hantzsch reaction, Biochem. J. 55 (1953) 416-421.

[36] L.A. Reinke, M.J. Mayer, $p$-Nitrophenol hydroxylation. A microsomal oxidation which is highly inducible by ethanol, Drugs Metab. Dispos. 13 (1985) 548-552.

[37] R.A. Lubet, M.J. Mayer, J.W. Cameron, W.N. Raymond, M. Burke, T. Wolf, F.P. Guengerich, Dealkylation of pentoxyresorufin. A rapid and sensitive assay for measuring induction of cytochrome(s) P450 by phenobarbital and other xenobiotics in rat, Arch. Biochem. Biophys. 238 (1985) 43-48.

[38] M.D. Burke, S. Thompson, C.R. Elcombe, J. Halpert, T. Haaparant, R.T. Meyer, Ethoxy-, pentoxy- and benzyloxyphenoxazones and homologues: a series of substrates to distinguish between different induced cytochromes P450, Biochem. Pharmacol. 34 (1985) 3337-3345.

[39] T.H. Van der Hoeven, Assay of hepatic microsomal testosterone hydroxylases by high-performance liquid chromatography, Anal. Biochem. 138 (1984) 57-65.

[40] O.H. Lowry, H.J. Rosenbrough, A.L. Farr, R.J. Randall, Protein measurement with Folin phenol reagent, J. Biol. Chem. 193 (1951) 265-275.

[41] Y.L. Bailey, Techniques in Protein Chemistry, Elsevier, Amsterdam, 1967, pp. 340-341.

[42] L. Valgimigli, G.F. Pedulli, M. Paolini, Measurement of oxidative stress by EPR radical-probe technique, Free Radic. Biol. Med. 31 (2001) 708-716.

[43] B. Gustavino, A. Buschini, M. Monfrinotti, M. Rizzoni, L. Tancioni, P. Poli, C. Rossi, Modulating effects of humic acids on genotoxicity induced by water disinfectants in Cyprinus carpio, Mutat. Res. 587 (2005) 103-113.

[44] G.P. Box, W.G. Hunter, Statistics for Experiments, Wiley, New York, 1978, pp. 80-82.

[45] R.K. Das, N.K. Nanda, Induction of micronuclei in peripheral erythrocytes of fish Heteropneustes fossilis bymitomycin $\mathrm{C}$ and paper mill effluent, Mutat. Res. 175 (1986) 67-71.

[46] K. Al-Sabti, Micronuclei induced by selenium, mercury, methylmercury and their mixtures in binucleated blocked fish erythrocyte cells, Mutat. Res. 320 (1994) 157-163.

[47] J.R. Gillette, B. Brodie, B.N. Ladu, The oxidation of drugs by liver microsomes: on the role of TPNH and oxygen, J. Pharmacol. Exp. Ther. 119 (1957) 532-540.

[48] M. Paolini, L. Pozzetti, G. Pedulli, M. Cipollone, R. Mesirca, G. Cantelli-Forti, Paramagnetic resonance in detecting carcinogenic risk from cytochrome P450 overexpression, J. Invest. Med. 44 (1996) 470-473.

[49] S. Puntarulo, A.I. Cederbaum, Production of reactive oxygen species by microsomes enriched in specific human cytochrome P450 enxymes, Free Radic. Biol. Med. 24 (1998) 13241330.

[50] L. Valgimigli, G. Pedulli, M. Paolini, Measurement of oxidative stress by EPR radical-probe technique, Free Radic. Biol. Med. 31 (2001) 708-716.

[51] K. Al-Sabti, M. Franko, B. Andrijanič, S. Knez, P. Stegnar, Chromium induced micronuclei in fish, J. Appl. Toxicol. 14 (1994) 333-336. 
[52] M. Paolini, J. Barillari, S. Trespidi, L. Valgimigli, G.F. Pedulli, G. Cantelli-Forti, Captan impairs CYP-catalyzed drug metabolism in the mouse, Chem. Biol. Interact. 123 (1999) 149170.

[53] M. Paolini, A. Antelli, L. Pozzetti, D. Spetlova, P. Perocco, L. Valgimigli, G.F. Pedulli, G. Cantelli-Forti, Induction of cytochrome P450 enzymes and over-generation of oxygen radi- cals in beta-carotene supplemented rats, Carcinogenesis 22 (2001) 1483-1495.

[54] A. Buschini, A. Martino, B. Gustavino, M. Monfrinotti, P. Poli, C. Rossi, M. Santoro, A.J.M. Dörr, M. Rizzoni, Comet assay and micronucleus test in circulating erythrocytes of Cyprinus carpio specimens exposed in situ to lake waters treated with disinfectants for potabilization, Mutat. Res. 557 (2004) 119-129. 